\title{
Laboratory Model Test on Improving the Properties of Soft Clay by Electrokinetics
}

\author{
Eltayeb Mohamedelhassan \\ Department of Civil Engineering, Lakehead University, 955 Oliver Road, Thunder Bay, ON, Canada P7B 5E1 \\ Correspondence should be addressed to Eltayeb Mohamedelhassan, eltayeb@lakeheadu.ca
}

Received 13 January 2011; Accepted 12 March 2011

Academic Editor: D. N. Singh

Copyright (๑) 2011 Eltayeb Mohamedelhassan. This is an open access article distributed under the Creative Commons Attribution License, which permits unrestricted use, distribution, and reproduction in any medium, provided the original work is properly cited.

\begin{abstract}
This experimental study was carried out in two test series to investigate the feasibility of decreasing the water content and increasing the shear strength and axial load capacity of laboratory-prepared soft clay by electrokinetic treatment. The focus of the investigations is the influence of pore fluid chemistry (fresh or highly saline water) on the gained improvement and on the energy consumption. The results showed that electrokinetics was effective in improving the properties of the soft clay with fresh and saline water. The degree of improvement, however, was superior in tests with freshwaters along with a lower energy consumption. The minimum water content and the maximum shear strength after the treatment were reported near the anode $(28 \% \pm 3.6$ and $99.3 \mathrm{kPa} \pm 15.4$ compared to $49.7 \% \pm 3.1$ and $12.1 \mathrm{kPa} \pm 1.7$ in the control). The maximum axial load capacity of the foundation model after the treatment was $416 \mathrm{~N}$ compared to $28 \mathrm{~N}$ in the control. The energy consumption varied between 69.1 and 1994.6 Whr.
\end{abstract}

\section{Introduction}

Soft soils and marine deposits are very common around the world. There are many infrastructure projects and coastal high-rise buildings whose foundations are often supported by such soils of low shear strength and high compressibility. The construction of these projects on soft soils can lead to a very expensive foundation system. Moreover, the installation of traditional foundation elements, particularly driven piles or caissons, can destroy any naturally existing cohesion or cementation between the soil particles and disturb the structure of the soil in the close vicinity of the foundation, causing excessive settlement and further reduction in the foundation's loading capacity.

Electrokinetic treatment is an effective and can be economically viable soil improvement technique to improve the geotechnical properties and increase the load capacity of foundations in soft soils, with minimum disturbance to the existing soil structure. Electrokinetics improves the strength properties of soils by inducing electrokinetic consolidation, generating electrokinetic cementation, and reducing the water content. The maximum negative porewater pressure,
$u_{e}(x)(\mathrm{kPa})$, that can be developed by electrokinetic consolidation is given by [1]

$$
u_{e}(x)=-\left(\frac{k_{e}}{k_{h}}\right) \gamma_{w} E x=\Delta \sigma^{\prime}
$$

where $k_{e}\left(\mathrm{~m}^{2} /(\mathrm{sV})\right)$ is the electroosmotic permeability, $k_{h}$ $(\mathrm{m} / \mathrm{s})$ is the hydraulic conductivity, $\gamma_{w}\left(\mathrm{kN} / \mathrm{m}^{3}\right)$ is the unit weight of water, $E(\mathrm{~V} / \mathrm{m})$ is the electric field intensity, $x(\mathrm{~m})$ is the horizontal distance from the anode, and $\Delta \sigma^{\prime}(\mathrm{kPa})$ is the increase in the effective stress.

In electrokinetic process, electrode reactions mainly control electrokinetic cementation. For example, in an electrokinetic treatment system with steel anode, the anode releases ferrous ions $\left(\mathrm{Fe}^{2+}\right)$ as the electrode is corroded by

$$
\mathrm{Fe}(\mathrm{s})-2 \mathrm{e}^{-} \longrightarrow \mathrm{Fe}^{2+}(\mathrm{aq}) .
$$

Further oxidation changes the ferrous ions to ferric ions $\left(\mathrm{Fe}^{3+}\right)$, that is,

$$
\mathrm{Fe}^{2+}(\mathrm{aq})-\mathrm{e}^{-} \longrightarrow \mathrm{Fe}^{3+}(\mathrm{aq}) .
$$


The ferrous and the ferric ions combined with oxygen to form $\mathrm{Fe}_{2} \mathrm{O}_{3}$ and $\mathrm{Fe}_{3} \mathrm{O}_{4}$. The formed iron oxides (natural cementing agents) precipitate into the soil's pores forming a cementation bonding between the soil particles. This was confirmed by previous researchers (e.g., $[2,3])$.

The flow rate of water, $Q_{e}\left(\mathrm{~m}^{3} / \mathrm{s}\right)$, drained by an electrokinetic process from a soil mass with area $A\left(\mathrm{~m}^{2}\right)$ perpendicular to the direction of flow is given by

$$
Q_{e}=k_{e} E A \text {. }
$$

In the laboratory, the electroosmotic permeability, $k_{e}$, is determined by applying a uniform electric potential across a soil mass with electrodes configuration in which the anode has free access to water and the cathode compartment open to the atmosphere. The volume of water collected at the cathode compartment during the test is measured, and (4) is used to determine $k_{e}[4,5]$.

The Helmholtz-Smoluchowski model is widely accepted by geotechnical researchers to interpret electrokinetic flow of water in soil [5]. According to the model, the movement of water in a liquid-filled capillary is induced by the electrical force, and the electroosmotic permeability is evaluated based on the balance of the electrical and frictional forces between the water and the capillary tube [6]:

$$
k_{e}=-\frac{\varepsilon_{w} \zeta n}{\mu},
$$

where $\varepsilon_{w}(\mathrm{~F} / \mathrm{m})$ is the permittivity of pore water, $\zeta(\mathrm{V})$ is the zeta potential, $n$ is the porosity of soil, and $\mu\left(\mathrm{Ns} / \mathrm{m}^{2}\right)$ is the dynamic viscosity of water. Since the HelmholtzSmoluchowski model was derived for a bundle of straight capillaries, a tortuosity factor, $\tau$, can be included in the model to account for the actual tortuous flow path encounter in soil $[7,8]$, that is,

$$
k_{e}=-\frac{\varepsilon_{w} \zeta \tau n}{\mu} .
$$

In (6), a negative $\zeta$ (zeta potential) value results in a positive $k_{e}$ (electroosmotic permeability). A positive $k_{e}$ means that the flow is towards the cathode. The permittivity and viscosity of soil pore water are approximately constant in the ranges of electrolyte concentrations commonly encountered in nature. The zeta potential (defined as the electrical potential at the solid-liquid interface), however, reflects the influence of the electrolyte composition, soil mineralogy, grain size, and electric charge. A higher zeta potential generally means a higher electroosmotic permeability and thereby a more effective electrokinetic consolidation and a higher drainage of water.

In electrokinetic treatment with a constant applied voltage, the electrical current $I(\mathrm{~A})$ is a time function due to the changes in the electrical conductivity of the soil-water system during the treatment. The total energy consumption, $P$ (Whr), over a treatment period is given by

$$
P=\beta U_{o} \int_{0}^{T} I \mathrm{dt}
$$

where $\beta$ is the intermittence factor:

$$
\beta=\frac{\text { Power ON time }}{\text { Power ON time }+ \text { Power OFF time }}
$$

$U_{o}(\mathrm{~V})$ is the applied voltage, and $T(\mathrm{hr})$ is the duration of treatment.

In this study, two test series were carried out to investigate the feasibility of improving the geotechnical properties of laboratory-prepared soft clay soil by electrokinetic treatment. The investigations included the influence of pore fluid chemistry (fresh or highly saline water) on the gained improvement and on the energy consumption.

(i) Test series 1 investigated the decrease in the water content and the increase in the undrained shear strength of the soft soil by electrokinetic treatment.

(ii) Test series 2 investigated the increase in the axial load capacity of a foundation model embedded in the soft soil by electrokinetic treatment in the vicinity of the model.

Test series 1 investigated the feasibility of improving the geotechnical properties that are relevant to the bearing capacity of a shallow foundation (i.e., undrained shear strength). The foundation model in series 2 represents a section of a deep foundation element embedded in soft clay. The foundation element simulated in series 2 relies primarily on the skin friction for its axial load capacity which is generally the case for large caissons.

\section{Experimental Program}

2.1. Soil Properties. The soil used in the study was a mixture of $95 \%$ (by weight) inorganic grey clay obtained from Plainsman Clay in Medicine Hat, Alberta, and 5\% bentonite (laboratory grade sodium montmorillonite). Kaolinite is the predominant clay mineral of the Plainsman Clay. The soft clay was prepared by mixing the dry clay mixture with water to water content of $60 \%$ (equivalent to the liquid limit of the clay mixture). The water content was selected equivalent to the liquid limit in order to produce a soil specimen with properties of reconstituted clay as described by Burland [9] and with virtually no shear strength. Three types of freshwater and a highly saline water were used to prepare the mix. The freshwaters were distilled water, water from Lake Superior (hereafter referred to as lake water), and tap water from the city of Thunder Bay, Ontario (hereafter referred to as tap water). The highly saline water was artificial seawater (hereafter referred to as A-seawater). A-seawater was prepared with chemical compositions and electrochemical properties typical of seawater. Table 1 summarizes the properties of the mixed clay and pore fluids.

2.2. Electrokinetic Cell and Testing Procedure. Four identical electrokinetic testing cells were designed and fabricated to perform the tests of the study. The two general design considerations of the cell were 
TABLE 1: Characteristics of the mixed clay and the pore fluids.

\begin{tabular}{|c|c|}
\hline Liquid limit & 60 \\
\hline Plastic limit & 21 \\
\hline Water content $(\%)^{*}$ & 60 \\
\hline Clay size $(\%)$ & 48 \\
\hline Silt size (\%) & 49 \\
\hline Sand size (\%) & 3 \\
\hline Specific gravity & 2.68 \\
\hline \multicolumn{2}{|l|}{ Distilled water: } \\
\hline Electrical conductivity, $\mathrm{mS} / \mathrm{cm}$ & 0.008 \\
\hline $\mathrm{pH}$ & 6.7 \\
\hline \multicolumn{2}{|l|}{ Lake water: } \\
\hline Electrical conductivity, $\mathrm{mS} / \mathrm{cm}$ & 0.1 \\
\hline $\mathrm{pH}$ & 7.2 \\
\hline \multicolumn{2}{|l|}{ Tap water: } \\
\hline Electrical conductivity, $\mathrm{mS} / \mathrm{cm}$ & 0.11 \\
\hline $\mathrm{pH}$ & 7.7 \\
\hline \multicolumn{2}{|l|}{ A-seawater: } \\
\hline Electrical conductivity, $\mathrm{mS} / \mathrm{cm}$ & 54.8 \\
\hline $\mathrm{pH}$ & 7.2 \\
\hline $\mathrm{Na}^{+}(\mathrm{mg} / \mathrm{L})$ & 11400 \\
\hline $\mathrm{K}^{+}(\mathrm{mg} / \mathrm{L})$ & 435 \\
\hline $\mathrm{Ca}^{2+}(\mathrm{mg} / \mathrm{L})$ & 271 \\
\hline $\mathrm{Mg}^{2+}(\mathrm{mg} / \mathrm{L})$ & 1305 \\
\hline $\mathrm{Cl}^{-}(\mathrm{mg} / \mathrm{L})$ & 19580 \\
\hline $\mathrm{SO}_{4}{ }^{2-}(\mathrm{mg} / \mathrm{L})$ & 2500 \\
\hline $\mathrm{CO}_{3}^{2}(\mathrm{mg} / \mathrm{L})$ & 270 \\
\hline
\end{tabular}

${ }^{*}$ Water content of soil specimen at preparation.

(i) vertical electrodes layout: the vertical electrodes configuration was selected for its practicality in field installation and the ease of electrode replacement;

(ii) capability to apply a surcharge load to the soil specimen: the surcharge load can be used to simulate insitu stress conditions and to produce soil samples with various void ratios.

The cell, constructed of clear Plexiglas plates $15 \mathrm{~mm}$ in thickness, has dimensions of $320 \times 125 \times 250 \mathrm{~mm}(L \times W \times$ $H$ ) and volume capacity of 10 litres. The voltage across a soil specimen during a test is monitored via four voltage probes installed along the base of the cell, as shown in Figure 1. The base of the cell is detachable to allow for easy recovery and minimum disturbance for the soil samples that to be used for subsequent parametric studies.

Four soft clay mixtures were prepared at water content of $60 \%$ using three types of freshwater (i.e., distilled water, tap water, and lake water) and a highly saline water (i.e., A-seawater). The soil was placed into cell in three layers. Each layer was rodded 25 times using steel rod, $16 \mathrm{~mm}$ in diameter and $450 \mathrm{~mm}$ long with a hemispherically shaped tip, to prevent the entrapment of air buckets. In each test the cell was filled to a height of $235 \mathrm{~mm}$ for a volume of 9.4 litres. The high water content of the soil and the thorough rodding during placement in the cell insured that the soil specimen is nearly, if not fully, saturated. A geotextile filter was placed on the top of soil specimen followed by the loading plate, as shown in Figures 1 and 2. In test series 2, the foundation model and the steel pipe electrodes were inserted into the soft soil prior to the top geotextile filter. After $24 \mathrm{hrs}$, a surcharge load of $40.8 \mathrm{~kg}$ (corresponding to a pressure of $10 \mathrm{kPa}$ ) was applied to the soil specimen via the loading plate in four increments of 5,10,20, and $40.8 \mathrm{~kg}$ over a period of 7 days. The settlement with time was reported for each load increment using two dial gauges mounted on the loading plate (see Figures 1 and 2). The load was increased to the next level after the primary consolidation from the previous load increment approached completions as indicated by the settlement-time curve. After the primary consolidation was completed or nearly completed (7 days after the first load was applied), the electric field was switched on for 7 days of electrokinetic treatment. The surcharge load was sustained on the soil specimen during the entire treatment period.

In test series 1 that investigated the decrease in the water content and the increase in the undrained shear strength, a DC voltage of $10 \mathrm{~V}$ was applied via two parallel-plate electrodes made of steel mesh. Each electrode was vertically placed adjacent to the inside face of the vertical geotextile filter and in direct contact with the soil specimen as shown in Figure 1. The electrode and the soil in contact had the same surface area which resulted in a uniform electric field throughout the cell. As the electric field was switched on, some of the water in the soil pores drained horizontally from the anode toward the cathode and then to the cathode compartment and eventually to the scaled column.

In series 2 which investigated the axial load capacity of steel foundation model, the model served as the anode and two steel pipe electrodes were serving as the cathode. The foundation model, $150 \times 100 \times 3 \mathrm{~mm}(L \times W \times T)$ and surface area of $31200 \mathrm{~mm}^{2}$, was placed in the centre of the electrokinetic cell as shown in Figure 2. The pipe electrodes, made of perforated steel pipe, $14 \mathrm{~mm}$ outside diameter, $10 \mathrm{~mm}$ inside diameter, and $150 \mathrm{~mm}$ long, were placed at $100 \mathrm{~mm}$ from both sides of the foundation model (see Figure 2). The pipe electrodes were filled with course sand to serve as vertical drains in addition to their primary role as the cathode. Two applied DC voltages, 6 and $10 \mathrm{~V}$, were used in test series 2 . As the electric field was turned on, part of the water in the soil pores transferred toward the two perforated pipe cathodes and via the course sand to the top geotextile filter. The water was then travelled by gravitational forces to the two water compartments and then to the scaled columns.

Current intermittence, the application of a pulse voltage at predetermined on/off intervals instead of a continuous DC voltage, was selected in this study for its superior outcome in electrokinetic applications as well as its effectiveness in reducing corrosion of electrodes [10-12]. Current intermittence intervals of $2 \mathrm{~min}$ on and $2 \mathrm{~min}$ off were implemented during both test series.

The volume of water collected during the test, settlement, electric current, and voltage distribution were periodically recorded during the testing period. For each of the electrokinetic treatment tests performed in this study, an identical 


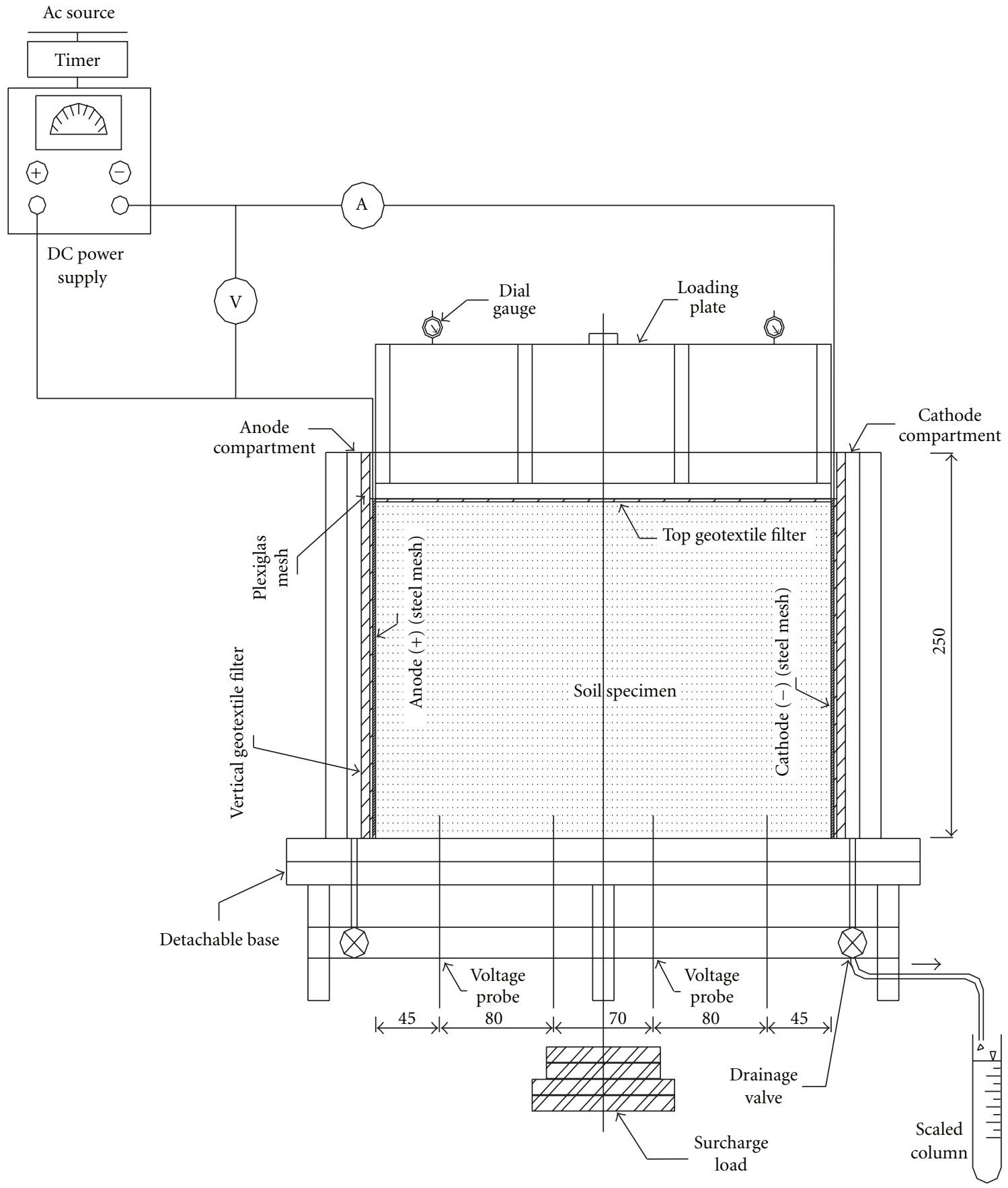

Figure 1: Elevation view of electrokinetic testing cell—configuration for test series 1 (dimensions in $\mathrm{mm}$ ).

control test with no applied electric field was conducted to provide baseline data (i.e., control) for comparison.

2.3. Surface Charge of Soil Solids. The surface charge properties of the clay mixture were measured as a function of the electrolyte chemistry using a zeta potential analyzer (Zeta Plus, Brookhaven Instruments Corporation). Zeta potentials were measured for soil solids suspended in (i) distilled water, (ii) lake water, and (iii) tap water. The zeta potential was unobtainable for the soil solids suspended in A-seawater as the high electrical conductivity of the solution was beyond the measuring range of the apparatus. The A-seawater was diluted to $10 \%, 27 \%$, and $40 \%$ of its original concentration, and the zeta potential was obtained using the diluted solutions. For each of soil suspensions, the measurements were repeated for at least ten times with the coefficient of variation (standard deviation/mean value) $\leq 10 \%$.

\section{Results and Discussion}

3.1. Electric Field. Figure 3 shows the voltage distribution across the soil specimen in test series 1 with applied voltage 


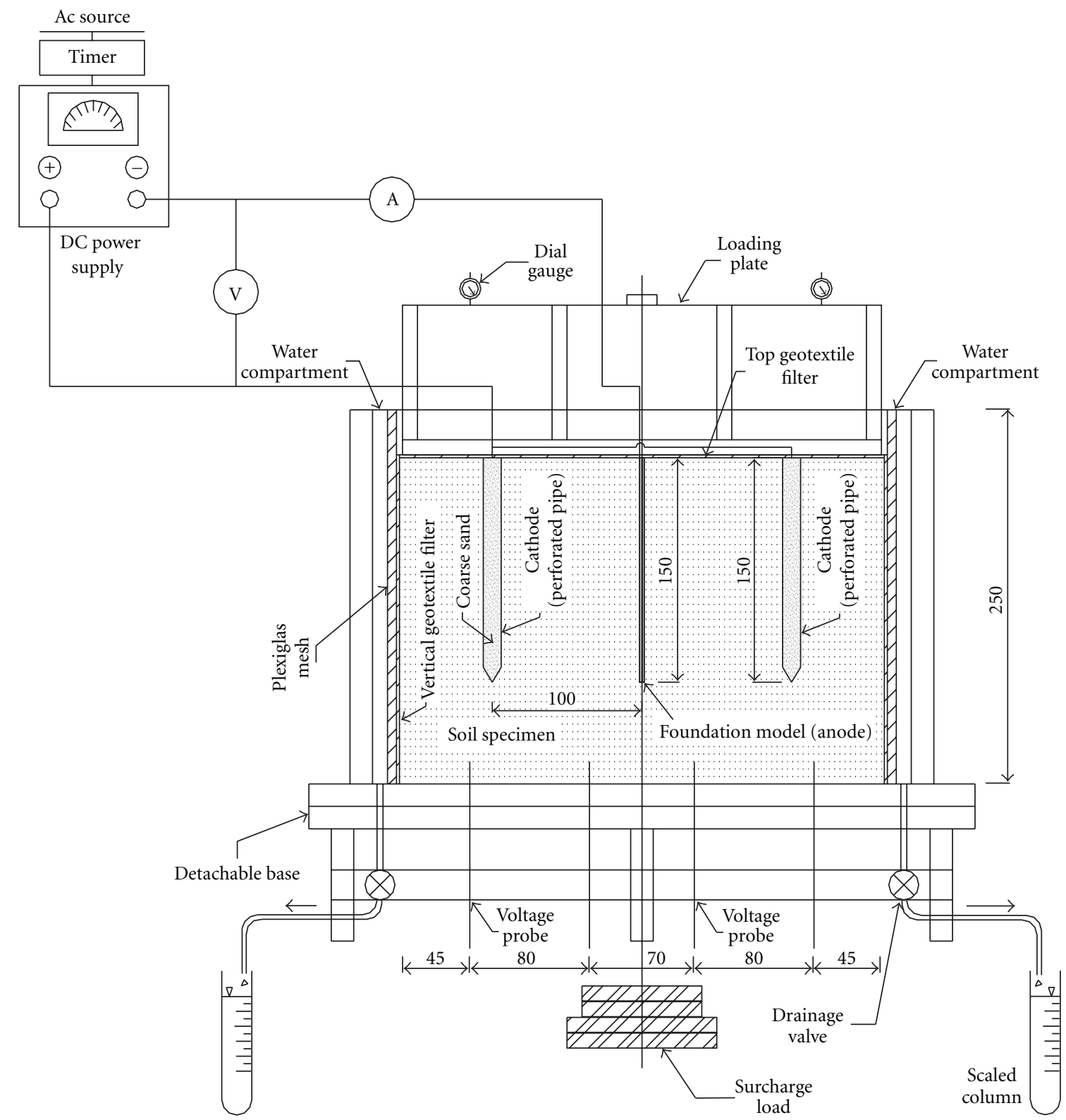

FIgURE 2: Elevation view of electrokinetic testing cell—configuration for test series 2 (dimensions in $\mathrm{mm}$ ).

of $10 \mathrm{~V}$. The voltage distribution was averaged over 7 days of treatment. The figure shows that the voltage distribution was fairly linear and almost identical for the tests with freshwater pore fluids (distilled water, lake water, and tap water). The distribution in the test with A-seawater pore fluid was slightly lower than in the previous tests.

Figure 4 shows the electric current through the soil in test series 1. As shown in the figure, the electric currents in the tests with the lake water and tap water pore fluids were almost identical in trend and in magnitude with a maximum current of $0.1 \mathrm{~A}$ at the start of the test and a minimum of $0.07 \mathrm{~A}$ at the end of the test. The test with the distilled water pore fluid exhibits a trend similar to the previous two tests and with a maximum current of $0.09 \mathrm{~A}$ at the start of the test. Figure 4 shows the electric current in the test with A-seawater pore fluid to be approximately 10 times the current in the freshwater tests. The higher current in the soil mixed with A-seawater can be attributed to higher electrical conductivity of the soil. The electrical conductivity of a soil mass is a product of the electrical conductivity of the two components of the soil, that is, soil solids (function of soil mineralogy) and soil pore fluid. In general, the electrical conductivity of the pore fluid is much higher than that of the soil solids and, thereby, dominates the bulk conductivity of the soil $[4,13]$. Since A-seawater has a much higher electrical conductivity $(54.8 \mathrm{mS} / \mathrm{cm})$ compared to the freshwater $(0.008$ to $0.11 \mathrm{mS} / \mathrm{cm}$, see Table 1$)$, the electrical conductivity of the soil prepared with A-seawater was much higher than the conductivity of the soil prepared by each of the freshwaters. This was reflected by the higher 


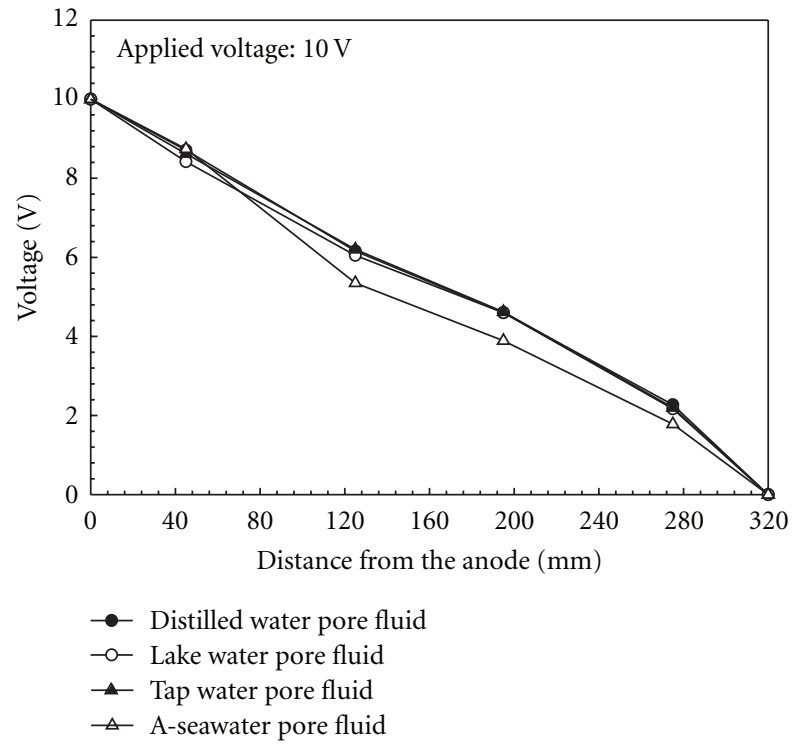

Figure 3: The average voltage distribution across the cell for test series 1 .

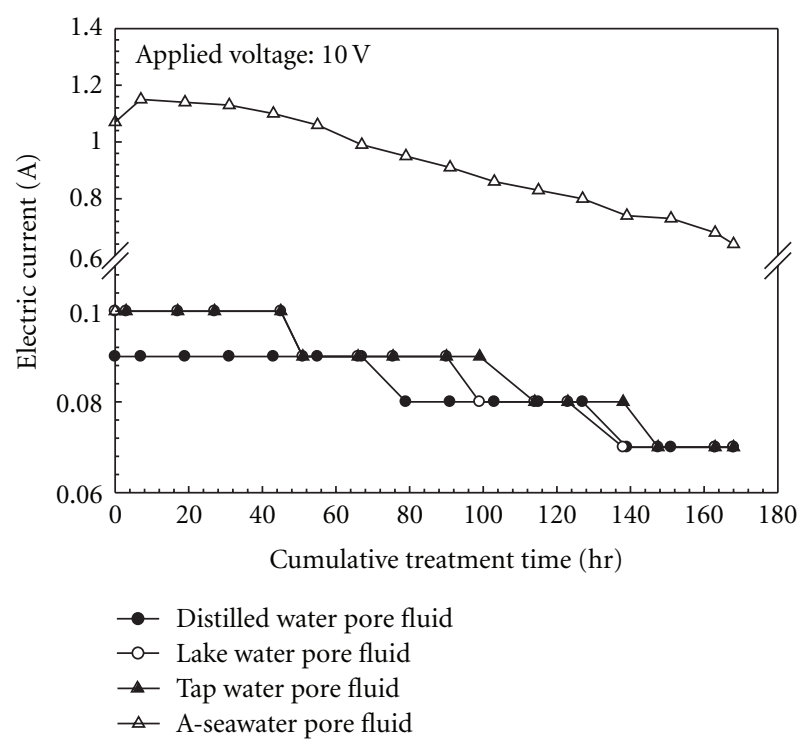

FIGURE 4: Electric current versus cumulative treatment time-test series 1 .

electric current in the test of the soil with A-seawater pore fluid as shown in Figure 4. Vice versa, the lowest current was reported in the test with distilled water pore fluid as electrical conductivity of the pore fluid was the lowest. The higher electric conductivity of the soil with A-seawater resulted in the lower voltage distribution across the soil as shown in Figure 3.

Figures 5(a) and 5(b) show the electric current in test series 2 with applied voltages of 6 and $10 \mathrm{~V}$, respectively. As seen in the figures, the electric currents in the tests with freshwater pore fluids and the same applied voltage were approximately similar in magnitude and trend. The current varied between $0.75 \mathrm{~A}$ and $0.2 \mathrm{~A}$ with the high values

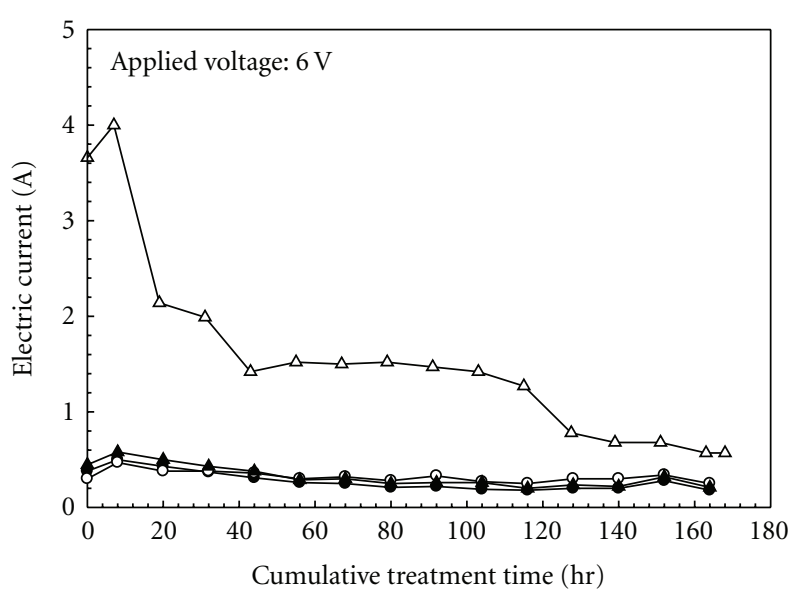

(a)

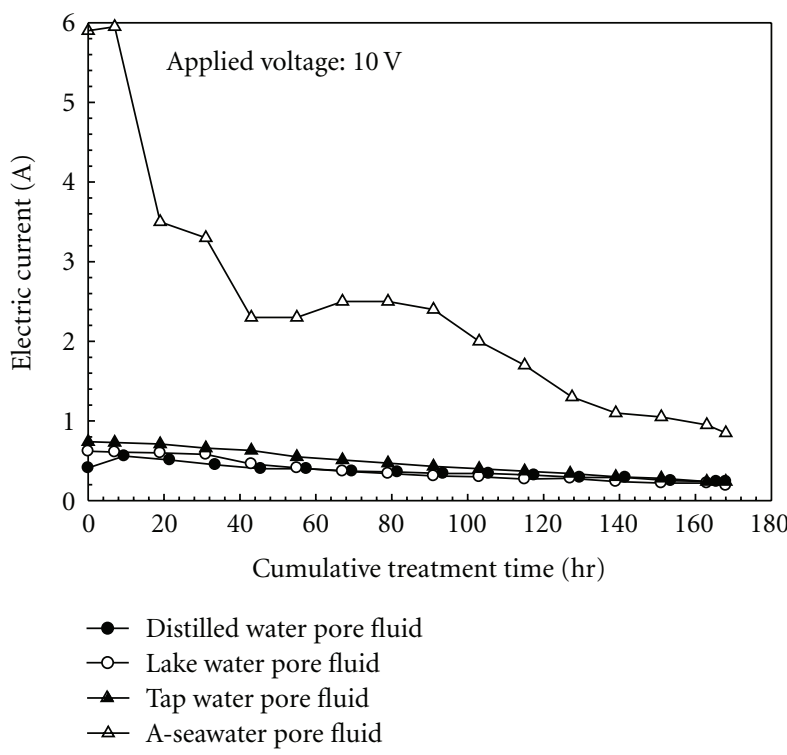

(b)

Figure 5: Electric current versus cumulative treatment time-test series 2. (a) Applied voltage: $6 \mathrm{~V}$; (b) applied voltage: $10 \mathrm{~V}$.

reported during the first $7 \mathrm{hrs}$ of the treatment while the low values were observed at the end of the test. The electric current in the tests with A-seawater pore fluid were much larger with a peak of $4 \mathrm{~A}$ for applied voltage of $6 \mathrm{~V}$ and $6 \mathrm{~A}$ for the $10 \mathrm{~V}$ reported during the first $7 \mathrm{hrs}$ of the test. The minimum currents were 0.6 and $0.9 \mathrm{~A}$ reported at the end of the test.

The decrease in electric current with time as shown in Figures 4, 5(a), and 5(b) resulted from the decrease in electrical conductivity of the soil during the treatment. The change in the conductivity of a soil during an electrokinetic treatment is a result of two opposing mechanisms. In general, as the pore fluid drained out of the soil mass (pore fluid dominates the bulk conductivity of the soil), the bulk electrical conductivity of the soil decreases. However, for water still remaining inside the soil pores, the electrical conductivity increases with the treatment time as a result of electrolytic reactions associated with the electrokinetic 
process $[8,14]$. Therefore, the increase in the electrical conductivity of the pore fluid by the electrolytic reactions can sometimes become more dominant than the decrease in conductivity of the soil resulting from the draining of water. Thus the bulk conductivity of the soil, and thereby the electric current, may start to increase sometime after the start of the electrokinetic treatment. The increase in current hours after the start of the treatment was observed in some of the tests (see Figures 4, 5(a), and 5(b)).

\subsection{Test Series 1: Water Content and Undrained Shear} Strength. The volume of water drained from the soil specimen in test series 1 was collected and measured in the scaled column shown in Figure 1. Figures 6(a)-6(d) show the cumulative volume of water collected during the 7 days ( $168 \mathrm{hrs}$ ) of consolidation prior to the electrokinetic treatment along with the water collected during the following 7 days of treatment. As seen in the figures, the cumulative volume collected in the control and in the treated specimens before the application of electric field was almost identical for all tests. However, after the application of electric field, with the exception of the test with A-seawater pore fluid, the volume of water collected from the treated soil was far more than that from the control. The cumulative volume of water collected in the electrokinetic tests with freshwater pore fluids (distilled water, lake water, and tap water) varied between 1201 and $1561 \mathrm{~mL}$ (387 to $399 \mathrm{~mL}$ collected prior to the application of electric filed). Thus, between $67 \%$ and $75 \%$ of the water was collected in 7 days of electrokinetic treatment. It is worth noting that the larger portion of the water was drained by electrokinetics although the water in the soil pores at the beginning of the treatment $(\sim 56 \%)$ was less than the water at the beginning of the consolidation $(60 \%)$. This illustrates the effectiveness of electrokinetic in removing water from clayey soil as compared with conventional methods such as preloading. The cumulative volume of water collected in the control tests varied from slightly 450 to $456 \mathrm{~mL}$ with 361 to $390 \mathrm{~mL}$ collected during the first 7 days of consolidation and 60 to $95 \mathrm{~mL}$ during the second week of consolidation. However, different results were observed in the test with the A-seawater pore fluid. As shown in Figure 6(d), from a cumulative volume of $1318 \mathrm{~mL}$ collected during the test, $713 \mathrm{~mL}$ (54\%) was drained during the first week by consolidation and $605 \mathrm{~mL}(46 \%)$ was collected during the following week of electrokinetic treatment. In the control test, a total volume of $770 \mathrm{~mL}$ was collected with $714 \mathrm{~mL}$ during the first week and $56 \mathrm{~mL}$ during the second week of the test.

The higher volume of water collected during consolidation (i.e., prior to electrokinetic treatment) in the soil with A-seawater pore fluid resulted from the more porous path for the water in the test. This is due to the collapse of the diffuse double layer associated with pore fluid with high salinity. As the double layer collapses, the permeability of the soil increases, and hence a wider path will be available for the water to flow in or out of the soil [6].

After completion of the tests in series 1 , the water content and the undrained shear strength were measured at 15 locations with equal volume across the cell as shown in Figure 7. At each location, two measurements for the undrained shear strength and the corresponding water contents were performed. Figures 8 (a) -8 (d) show the water content across the cell for the four tests. The value of water content at each location was averaged from six measurements (e.g., at $32 \mathrm{~mm}$ from the anode, two measurements for each of samples A1-A3). As seen in Figures 8(a)-8(d), the trend of the water content in the control tests is similar and fairly symmetrical with slightly lower water content near the electrodes (i.e., samples Ai and Ei, drainage path of $32 \mathrm{~mm}$ ) and slightly higher water content at the centre (i.e., samples $\mathrm{Ci}$, drainage path of $160 \mathrm{~mm}$ ). The water contents in the tests with freshwater pore fluids were fairly similar in magnitude with maximum of $57.7 \% \pm 4.2$ at the centre and minimum of $53 \% \pm 3.53$ near the electrodes. In accordance with the higher volume of water drained in the test with A-seawater pore fluid, Figure $8(\mathrm{~d})$ shows the water contents in the test to be lower than the values of the previous tests.

Figures $8(a)-8(d)$ show that the electrokinetic treatment had decreased the water content across most of the soil specimen (the only exception was near the cathode) as compared with the control. The lowest water content was reported near the anode, and the water content increases toward the cathode. This is in full agreement with electrokinetic dewatering of soils as water is drained from the anode toward the cathode. Figures $8(a)-8(c)$ show a drastic difference between the water content near the anode $(28 \% \pm 3.6$ to $31 \% \pm 1)$ and the water content near the cathode $(62.7 \% \pm$ 7.6 to $68.7 \% \pm 8$ ) for the three tests with freshwater pore fluid. However, for the test with A-seawater pore fluid the difference in water content near the anode $(40.7 \% \pm 1.5)$ and near the cathode $(50.3 \% \pm 2.3)$ is less significant as shown in Figure 8(d). As electrokinetics removes water in the soil pores from the anode toward the cathode, the magnitude of the removed water will dictate the difference in water content near the electrodes. Thus, while 67 to $75 \%$ of the cumulative volume of water was removed by electrokinetics in the tests with freshwater pore fluids, only $46 \%$ was removed by electrokinetics in the test with A-seawater. This explains the drastic difference between the water contents near the electrodes for the former and the mild difference for the latter.

Figures 9(a)-9(d) show the undrained shear strength across the cell measured using Torvane (Soiltest Torvane CL-600A). Similar to the water content, the undrained shear strength at each location was averaged from six measurements. As seen in the figures, the trend of the undrained shear strength in the control tests is similar and fairly symmetrical with slightly higher values near the electrodes (i.e., samples Ai and Ei). This is in agreement with the lower water content reported in locations $\mathrm{Ai}$ and $\mathrm{Ei}$ as previously discussed. In addition to the similarity in trend, Figures 9(a)-9(c) show that the undrained shear strengths in the three tests with freshwater pore fluids were fairly similar in magnitude with values from $5.7 \mathrm{kPa} \pm 2.3$ to $6.6 \mathrm{kPa} \pm$ 1.7 at the centre and $7.4 \mathrm{kPa} \pm 1.5$ to $8.3 \mathrm{kPa} \pm 2.9$ near the electrodes. Figure 9 (d) shows that the average undrained shear strength in the control test with A-seawater pore fluid is 


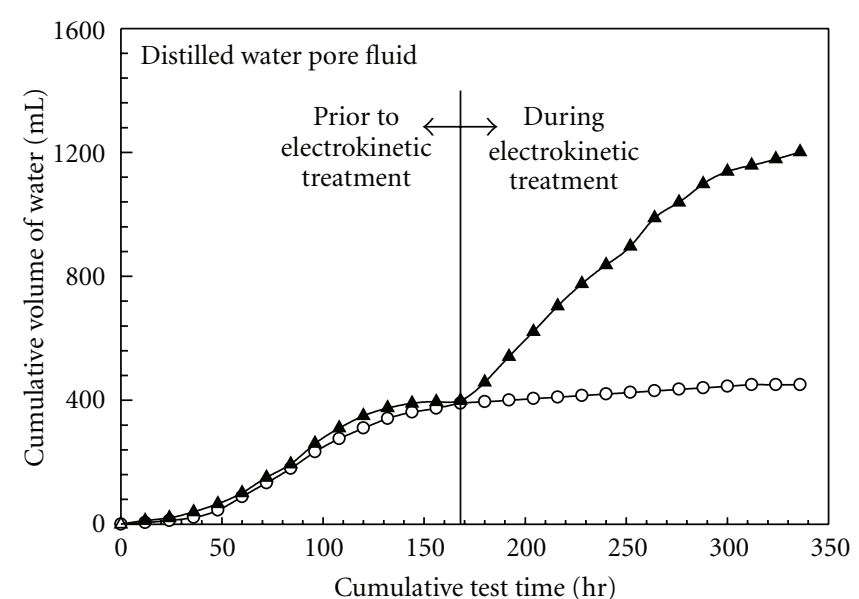

(a)

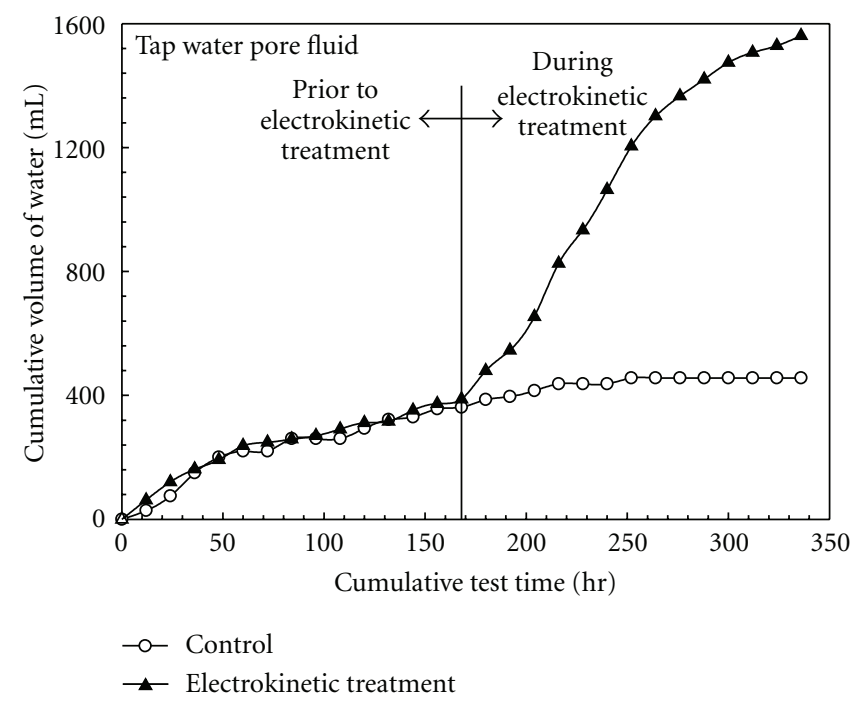

(c)

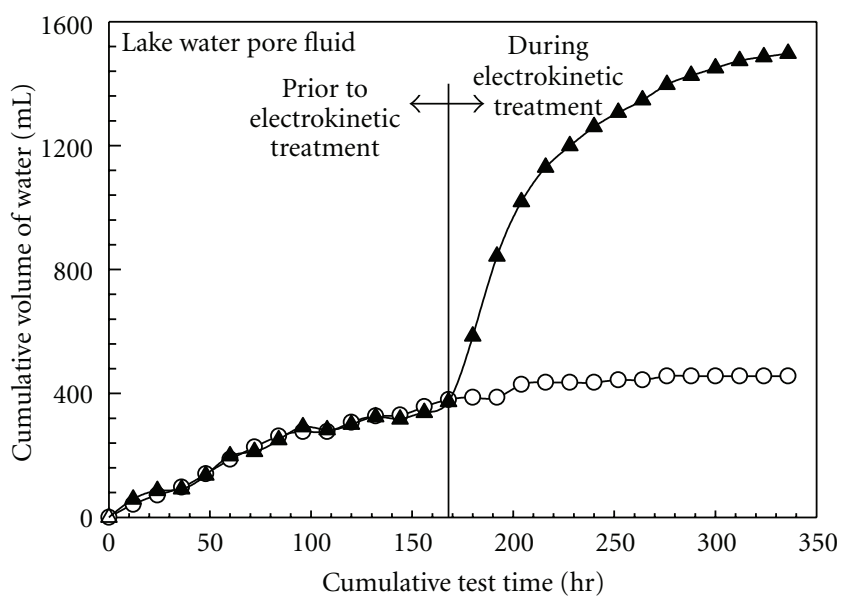

(b)

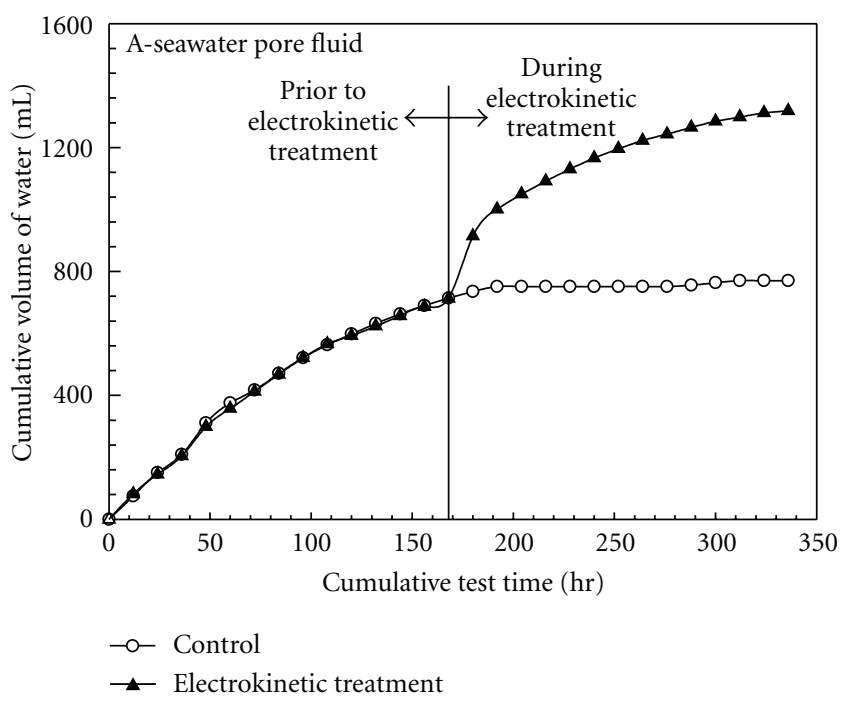

(d)

Figure 6: Cumulative volume of water collected prior to—and during electrokinetic treatment— test series 1.

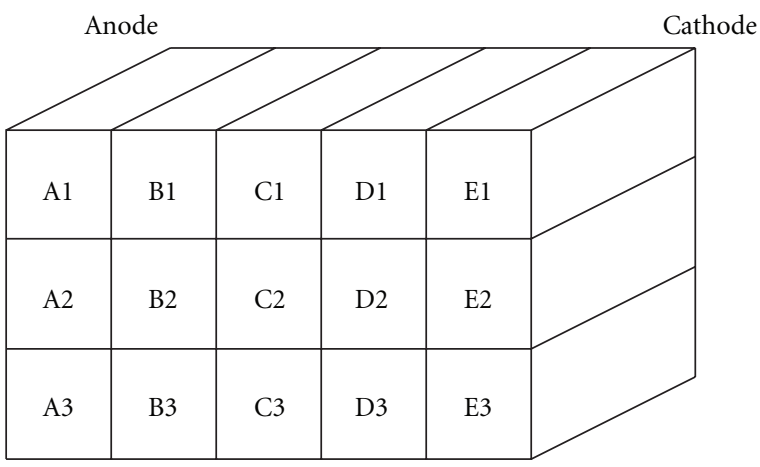

FIGURE 7: Schematic of the samples used for water content and undrained shear strength measurements-test series 1 .

in general higher than the values of the previous tests which is in agreement with lower values reported for the water content as previously discussed.
As indicated by the values of the water content, Figures 9(a)-9(d) show that in the electrokinetic treatment tests the highest undrained shear strength was reported near the anode (the lowest water content) and that the undrained shear strength decreased toward the cathode (the higher water content). The highest undrained shear strength was observed in the test with tap water pore fluid $(99.3 \mathrm{kPa}$ $\pm 15.4)$, followed by that of lake water $(85.4 \mathrm{kPa} \pm 10.7)$, distilled water $(60.5 \mathrm{kPa} \pm 5.5)$, and the A-seawater $(40.9 \mathrm{kPa}$ \pm 4.1 ). For each of the three tests with freshwater pore fluids, the undrained shear strength near the cathode (samples Ei) was the lowest and approximately similar to that of the control test (see Figures 9(a)-9(c)). However, in the test with A-seawater pore fluid (Figure 9(d)) the lowest undrained shear strength was not the nearest to the cathode, rather it was at $96 \mathrm{~mm}$ from the cathode (samples Di). This is likely due to the cementation resulting from the precipitation of cations in the A-seawater pore fluid near the cathode. In an electrokinetic process, electromigration causes the movement of ions in soil pore fluid towards the oppositely 


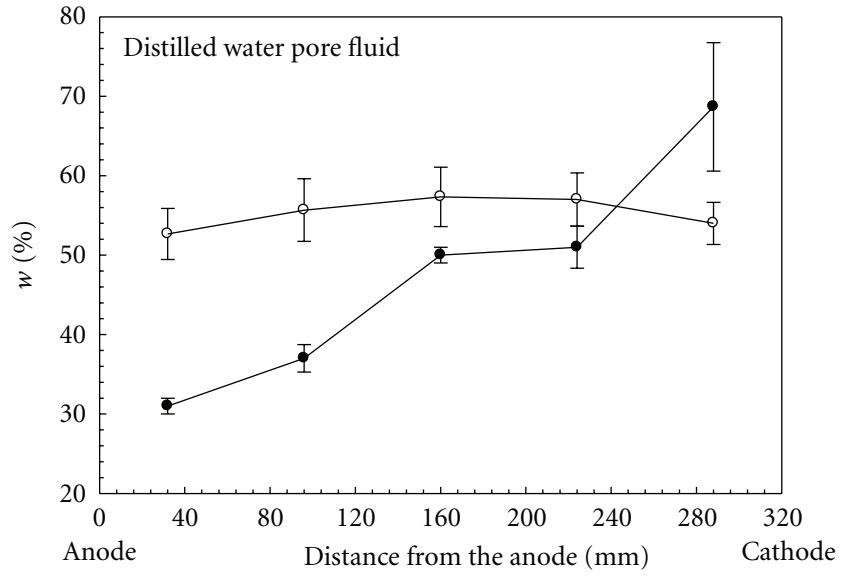

(a)

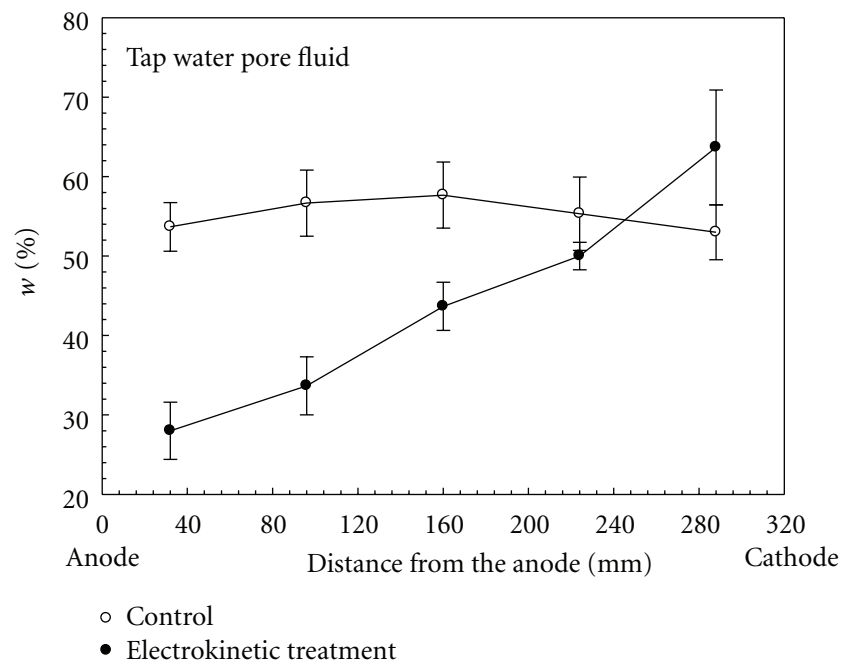

(c)

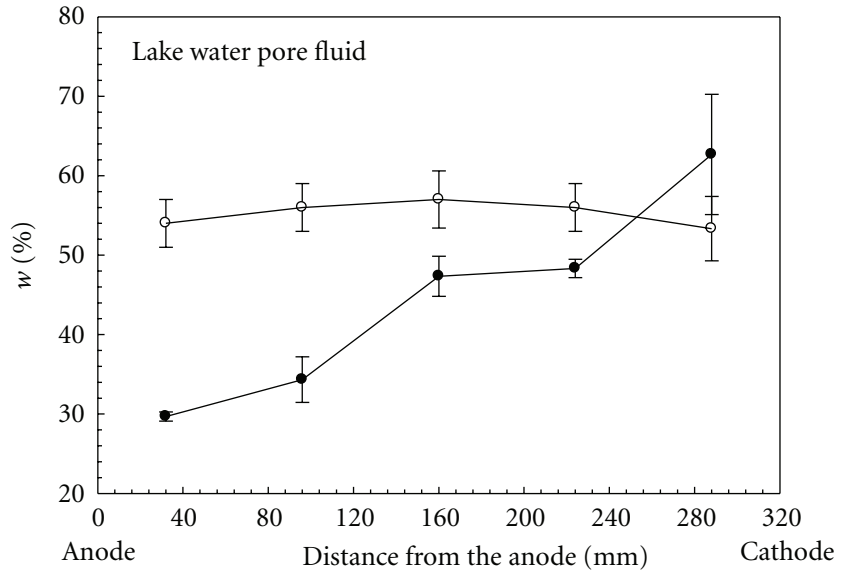

(b)

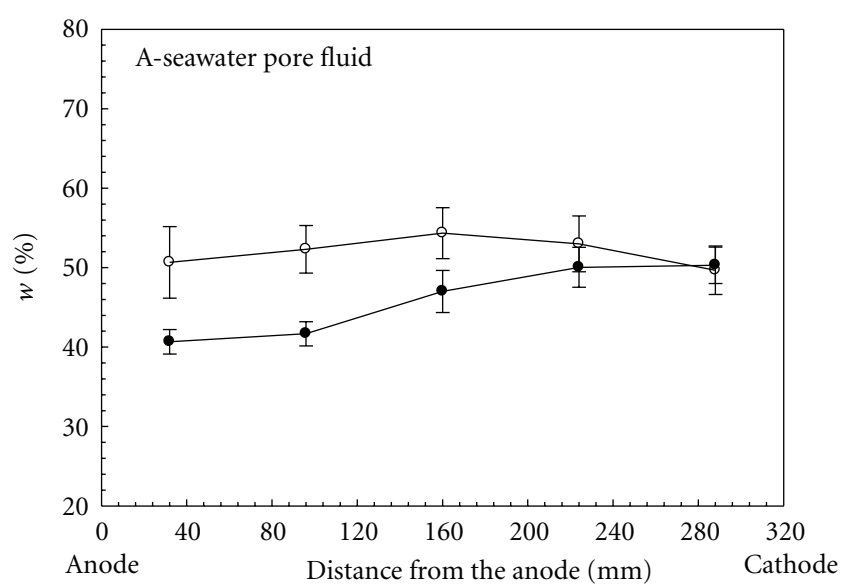

- Control

- Electrokinetic treatment

(d)

Figure 8: Water content, $w$, versus distance from anode-test series 1.

change electrode. Thus, the cations in the A-seawater pore fluid (see Table 1) will move by electrokinetics toward the cathode. The electrolysis of water in an electrokinetic process releases $\mathrm{H}^{+}$ions at the anode and $\mathrm{OH}^{-}$ions at the cathode. As a result, an acidic region is created near the anode and a basic region near the cathode. The high $\mathrm{pH}$ of soil near the cathode (9.5) caused the precipitation of the cations (e.g., $\mathrm{Ca}^{2+}$ ) generating cementation and a higher shear strength.

In electrokinetic treatment the increase in the undrained shear strength is not attributed to the decrease in the water content alone. The increase is also due to the generation of cementation compounds such as iron oxides as illustrated by (2) and (3). In a previous study by the author [15], it was found that the amount of iron oxides in the soil within the treatment zone had increased by more than 15 times after an electrokinetic treatment with steel electrodes as compared with the control. In this study, the evidence of the cementation can be qualitatively concluded by comparing Figures 8 and 9. As seen in Figure 8, the water content near the cathode after electrokinetic treatment for each of the tests was higher than the water content in the control. However, as shown in Figure 9, the undrained shear strength near the cathode after electrokinetic treatment in each test was similar to or higher than (by up to $100 \%$ in the test with A-seawater) that of the control test in spite of the higher water content, indicating a contribution to the shear strength from another source such as cementation.

The results from series 1 clearly show that, in an electrokinetic treatment, the distance from the anode dominates the increase in the shear strength of the soil. While the increase of shear strength in samples near the anode was quite substantial, only moderate to negligible increases were seen in samples away from the anode. This limitation must be considered and incorporated in the design and layout of electrokinetic treatment system for field applications. For example, polarity reversal of electrodes can be used to provide somewhat similar increases in the shear strength across the treated soil.

3.3. Test Series 2: Axial Load Capacity. After completion of the electrokinetic treatment in test series 2 (see Figure 2), the foundation model was axially loaded to failure by a 


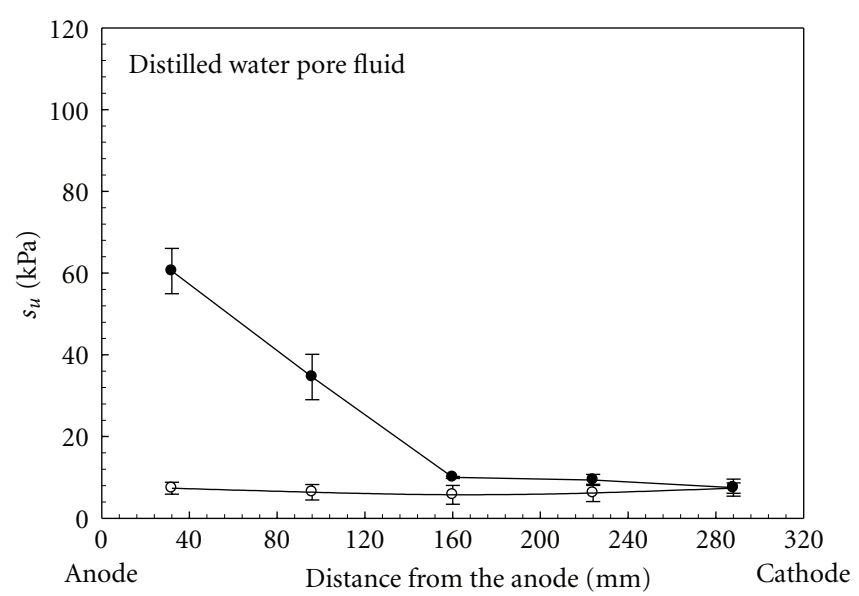

(a)

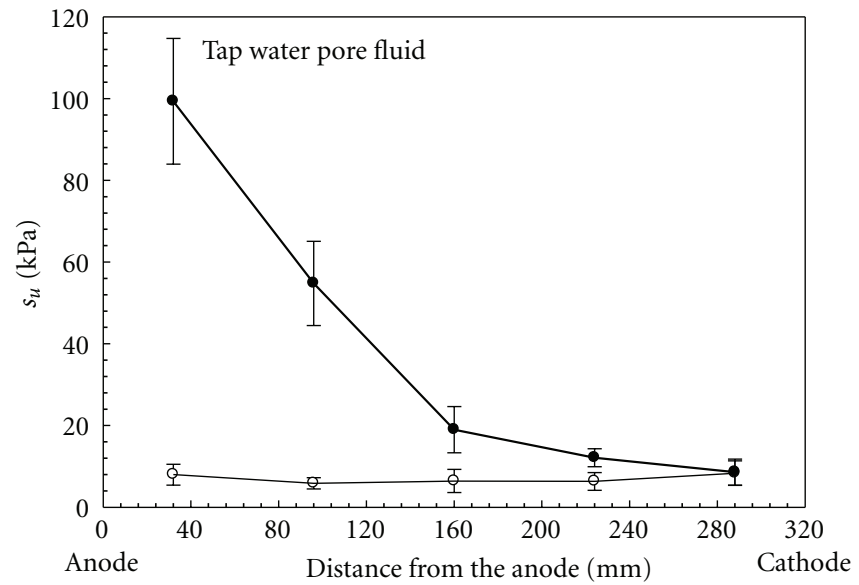

- Control

- Electrokinetic treatment

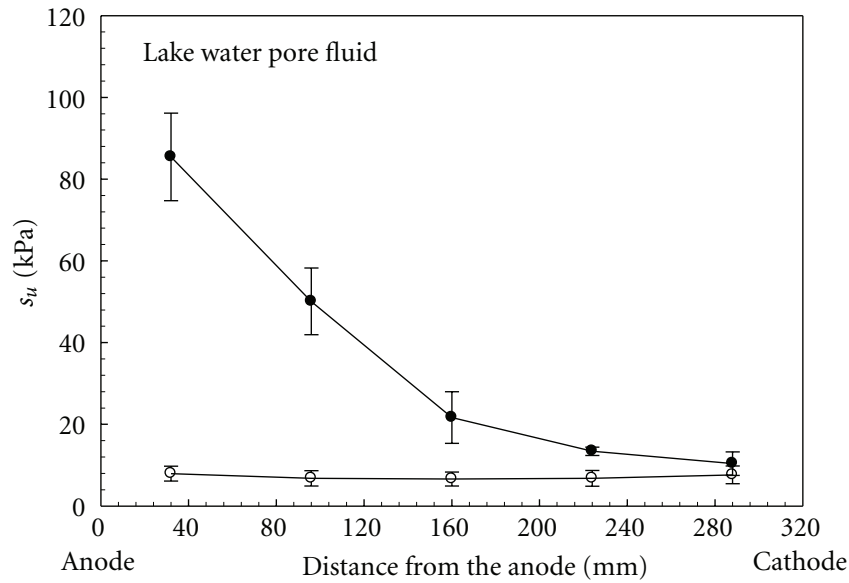

(b)

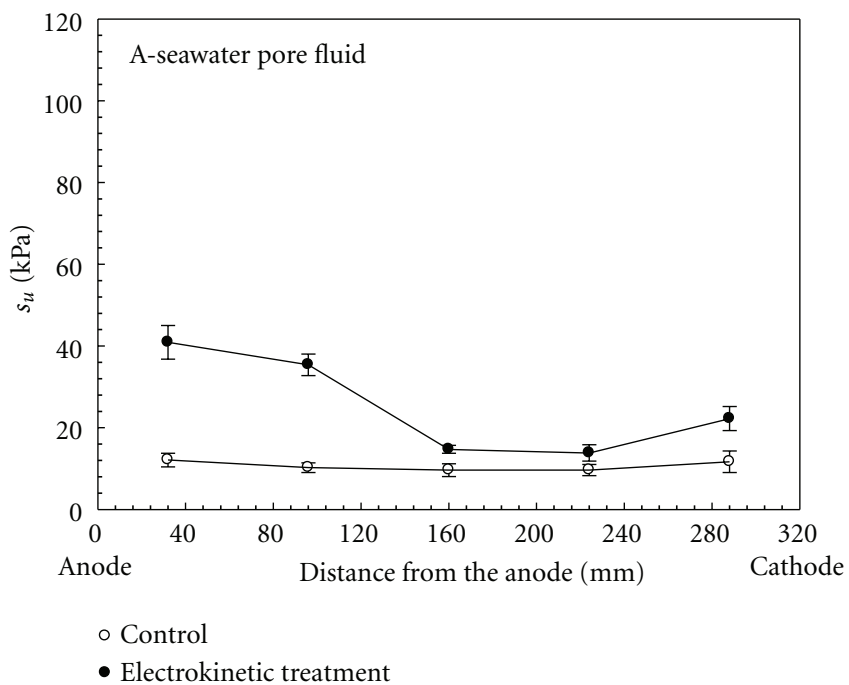

(d)

Figure 9: Undrained shear strength, $s_{u}$, versus distance from anode-test series 1.

triaxial load frame at a rate of $0.3 \mathrm{~mm} / \mathrm{min}$. Figures 10 (a)$10(\mathrm{~d})$ show the axial load capacity, $Q_{c}(\mathrm{~N})$, versus the vertical displacement of the model after the electrokinetic treatment and for the control tests. The axial load capacity at failure, $\left(Q_{c}\right)_{f}$, is defined as the point of intersection of the axial load capacity-displacement curve and the angle made by the two tangents on the two sides of the sharp bend of the curve [16]. As shown in Figure 10, $\left(Q_{c}\right)_{f}$ after electrokinetic treatment with $6 \mathrm{~V}$ was $166 \mathrm{~N}$ at a displacement of $2.3 \mathrm{~mm}$ in the test with distilled water pore fluid, $265 \mathrm{~N}$ at $2.4 \mathrm{~mm}$ in the test with lake water, $325 \mathrm{~N}$ at $3.3 \mathrm{~mm}$ in the test with tap water, and $165 \mathrm{~N}$ at $1.9 \mathrm{~mm}$ in the test with A-seawater. The corresponding $\left(Q_{c}\right)_{f}$ values in the control tests were 28, 27,28 , and $52 \mathrm{~N}$, respectively. This represents an increase between 217 and $1061 \%$ as compared to the control. After electrokinetic treatment with $10 \mathrm{~V},\left(Q_{c}\right)_{f}$ was $208 \mathrm{~N}$ at a $2.4 \mathrm{~mm}$ in the test with distilled water pore fluid, $345 \mathrm{~N}$ at $2.4 \mathrm{~mm}$ in the test with lake water, $416 \mathrm{~N}$ at $3.2 \mathrm{~mm}$ in the test with tap water, and $207 \mathrm{~N}$ at $1.9 \mathrm{~mm}$ in the test with Aseawater, representing an increase between 298 and 1386\% compared to the control.
As the foundation model represents a section of a deep foundation element embedded in clayey soil, the axial capacity of foundation is a function of the undrained shear strength at the soil-foundation interface. Figures $11(\mathrm{a})-11(\mathrm{~d})$ show the undrained shear strength of the soil across the cell. The shear strength was averaged from six measurements. After electrokinetic treatment with $6 \mathrm{~V}$, Figure 11 shows the undrained shear strength in the vicinity of the foundation model ranged between $25.7 \mathrm{kPa} \pm 3.6$ and $47.6 \mathrm{kPa} \pm 4$ compared to $7.5 \mathrm{kPa} \pm 1$ to $10.9 \mathrm{kPa} \pm 0.2$ in the control. After electrokinetic treatment with $10 \mathrm{~V}$, the undrained shear strength was $38.3 \mathrm{kPa} \pm 4.4$ to $64.2 \mathrm{kPa} \pm 5$. As per Figures 10 and 11, the increase in $\left(Q_{c}\right)_{f}$ was found to be proportional to the increase in the shear strength, confirming the correlation between the shear strength at the soil-foundation interface and the axial capacity of a deep foundation.

Figures 11(a) and 11(d) show that electrokinetics was effective in increasing the undrained shear in the vicinity of the foundation model and thereby increased the axial load capacity of the model while the shear strength away from the model remained approximately similar to that of the 


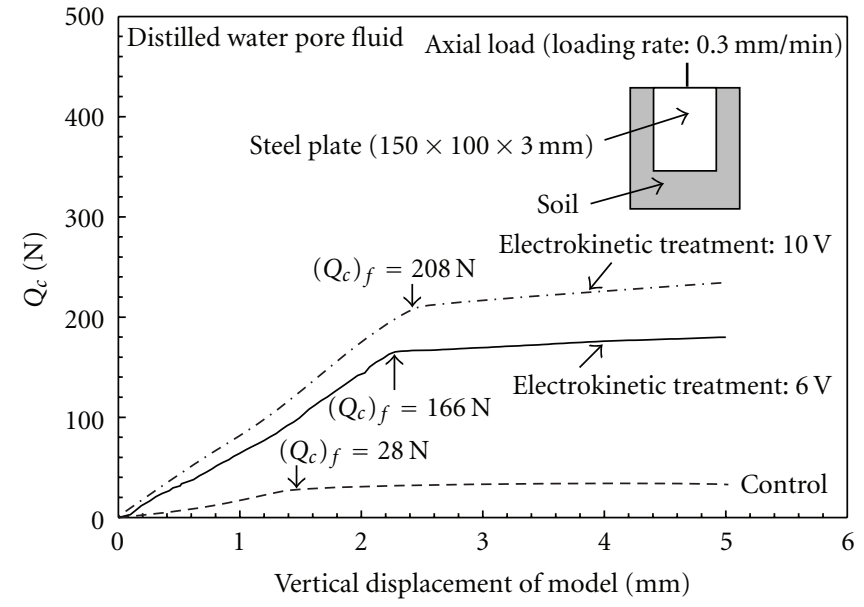

(a)

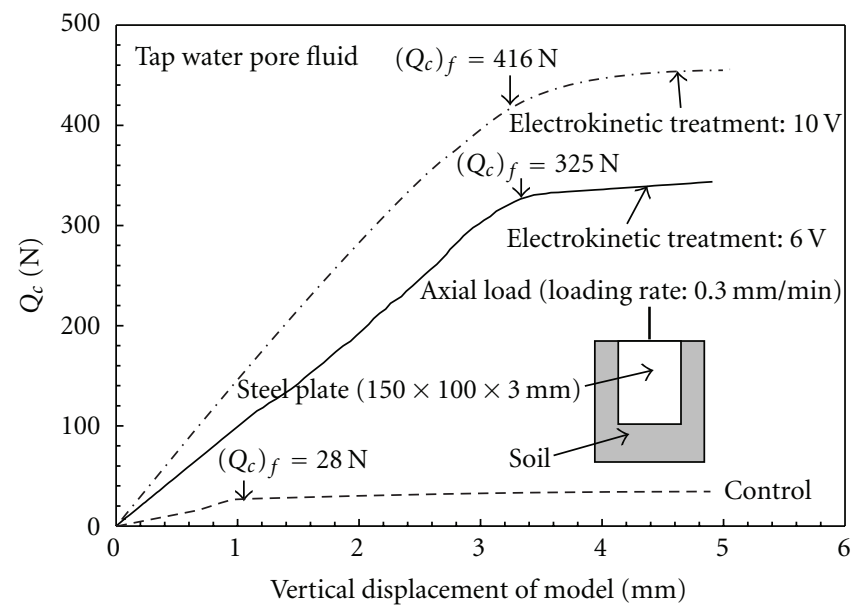

(c)

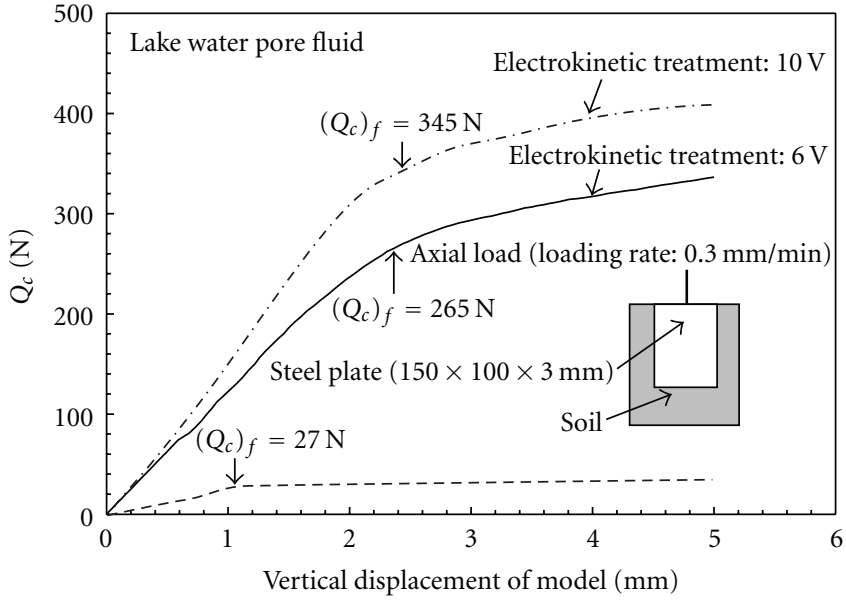

(b)

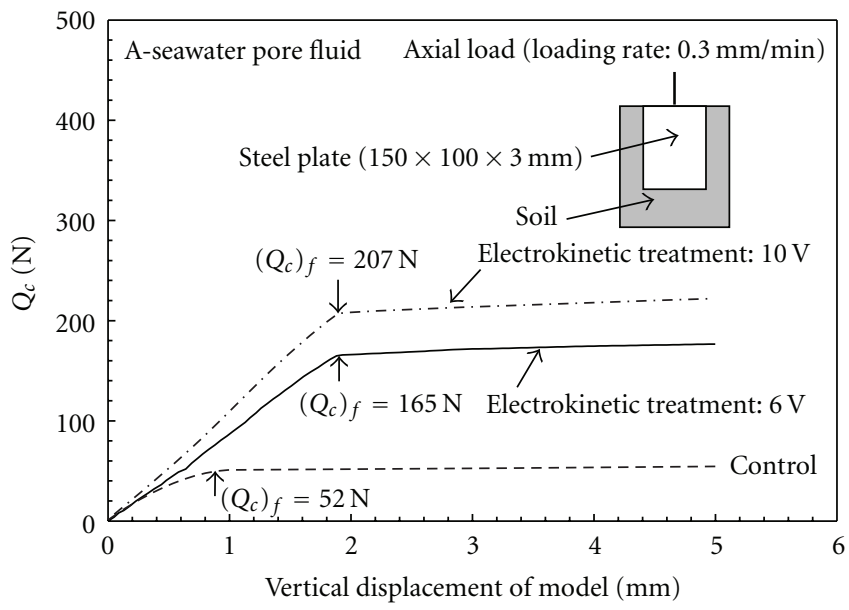

(d)

FIGURE 10: Axial load capacity, $Q_{c}$, versus vertical displacement of the foundation model—test series 2.

control test. Focusing the treatment and the shear strength improvement in the vicinity of a foundation element is very important in reducing the energy consumption of an electrokinetic treatment for full-scale applications, and yet it can lead to a significant increase in the axial load capacity of the element as illustrated by series 2 .

\subsection{Zeta Potential and Improvement of the Geotechnical Prop-} erties. The zeta potential of the soil was measured with the clay solids suspendered in each of the three freshwaters and diluted A-seawater. The average zeta values are summarized in Table 2. As shown in the table, the largest zeta potential (i.e., the most negative) was found in clay suspension with tap water, followed by that with lake water and distilled water, respectively. Lower zeta potential values were found in the clay suspension with diluted A-seawater, and zeta values were decreasing as the concentration increases.

In both test series the largest volume of drained water, the highest decrease in water content, the biggest increases in the undrained shear strength, and the largest axial load capacity of the foundation model after electrokinetic treatment were
TABLE 2: Zeta potential of the soil solids suspension.

\begin{tabular}{lc}
\hline Suspension fluid & Zeta potential $(\mathrm{mV})$ \\
\hline Distilled water & $25 \pm 2.1$ \\
Lake water & $28 \pm 2.3$ \\
Tap water & $32 \pm 2$ \\
$10 \%$ A-seawater & $15 \pm 1.3$ \\
$27 \%$ A-seawater & $11+1$ \\
$40 \%$ A-seawater & $9+0.8$ \\
\hline
\end{tabular}

consistently reported in the tests with tap water pore fluid followed by those with lake water, distilled water, and A-seawater, respectively. By comparing the improvement in geotechnical properties of the soil after electrokinetic treatment to the magnitude of the zeta potential, the improvement was found to increase with the increase of the zeta potential. This is in agreement with the HelmholtzSmoluchowski theoretical model (5). In the model, as the zeta potential increases, the electroosmotic permeability increases and the effectiveness of electrokinetics to drain 


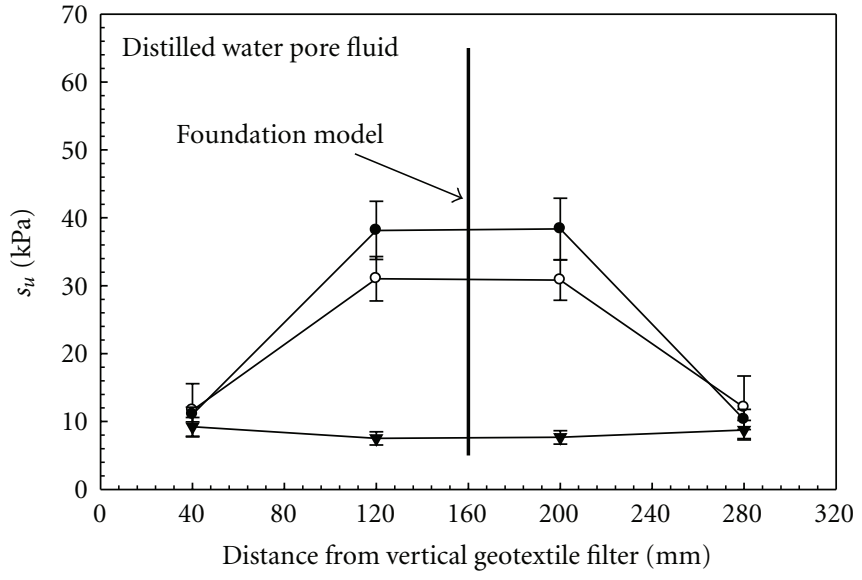

(a)

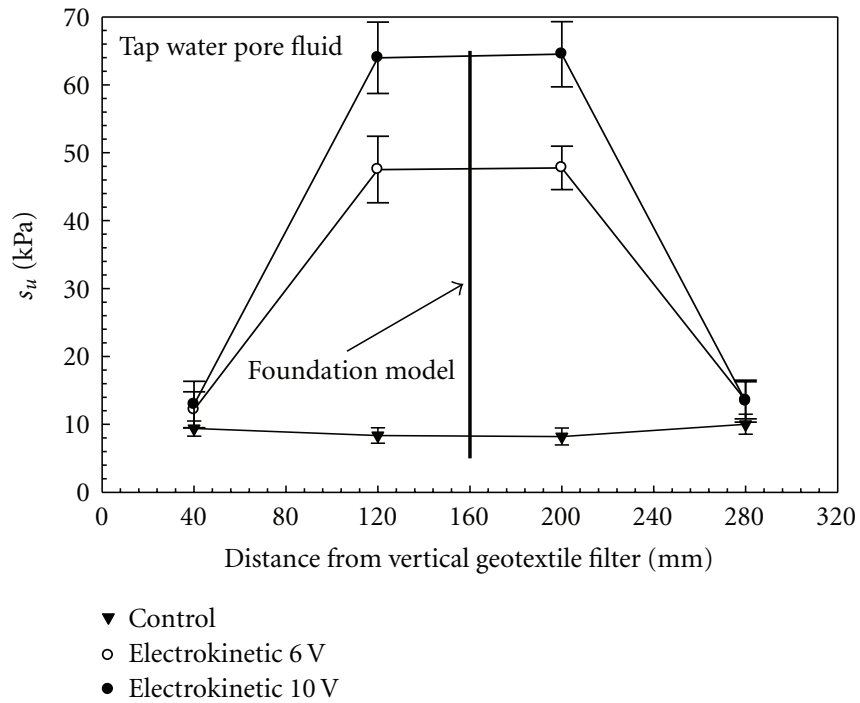

(c)

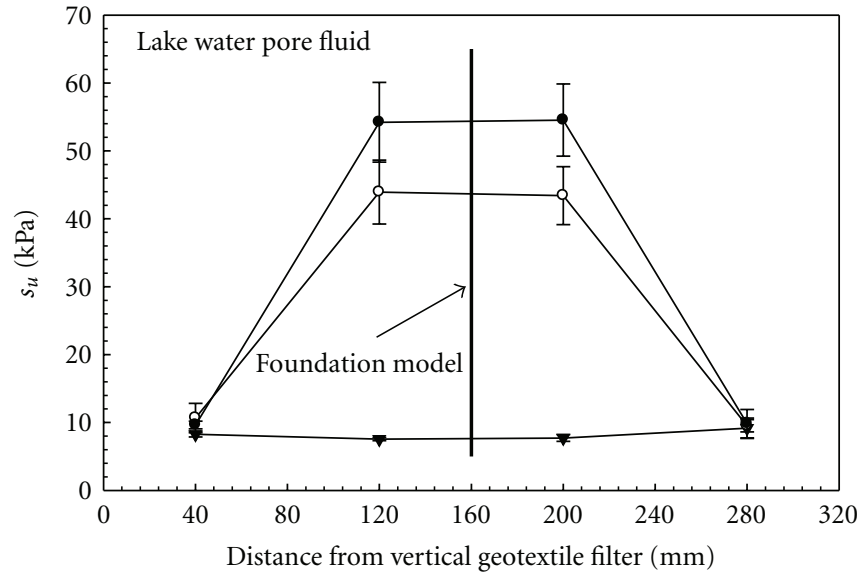

(b)

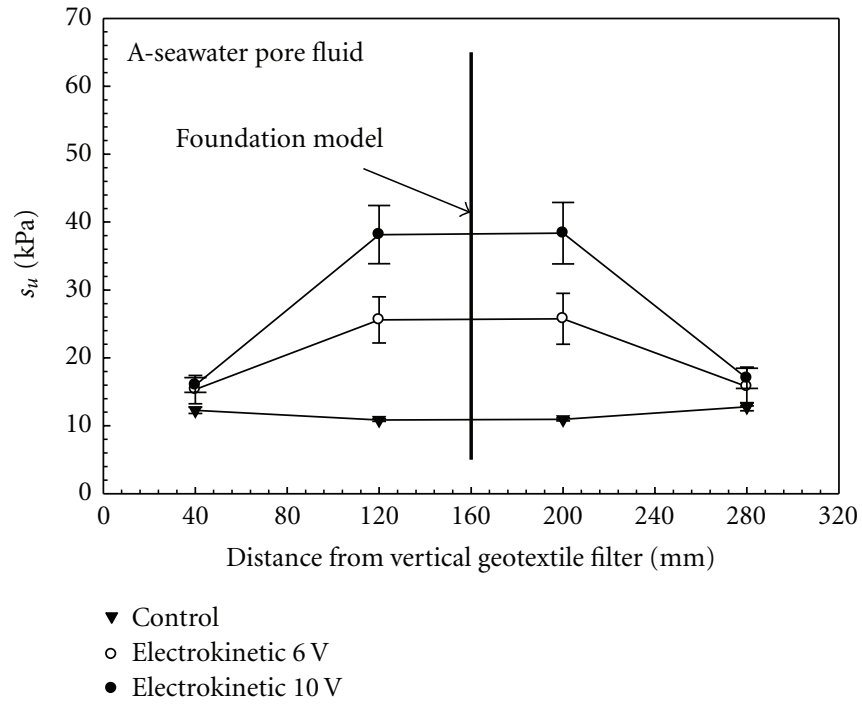

(d)

FIGURE 11: Undrained shear strength, $s_{u}$, versus distance from vertical geotextile filter-test series 2 .

water, generate consolidation, and increase the shear strength increases.

For the same soil solids, the magnitude of the zeta potential is influenced by the chemical properties of the soil's pore fluid in terms of $\mathrm{pH}$ and electrical conductivity [17]. For fluids with similar electrical conductivity, the zeta potential increases with the increase of the fluid $\mathrm{pH}$. At the same $\mathrm{pH}$, the zeta potential decreases with the increase of the electrical conductivity of the fluid [17]. As shown in Table 1, the electrical conductivity for three freshwaters (distilled water, lake water, and tap water) was very small and may have little influence on the magnitude of the zeta potential. For the three freshwaters, the highest $\mathrm{pH}$ and zeta potential of the soil suspension were for tap water followed by those of lake water and distilled water, respectively, indicating the dominant influence of $\mathrm{pH}$ on the zeta potential at a low electrical conductivity. As shown in Table 1, the electrical conductivity of the A-seawater pore fluid is significantly high compared with the conductivities of the three freshwaters (more than 500 times), which leads to a significant decrease in the zeta potential $[14,17]$ and thereby the least improvement in the properties of the soil by electrokinetic treatment as were the findings of this study.

\section{Energy Consumption and Foundation Model Corrosion}

The energy consumption during electrokinetic treatment was calculated for each test and is summarized in Table 3. In test series 1 the energy consumption for the tests with freshwater pore fluids (distilled water, lake water, and tap water) varied slightly from 69.1 to $73.7 \mathrm{Whr}$ (7.4 to $7.8 \mathrm{kWhr}$ per $\mathrm{m}^{3}$ of treated soil) with the lowest consumption in the test with distilled water and the highest in the test with tap water. The energy consumption in the test with A-seawater, however, was more than 11 times that of the previous tests (784.7 Whr or $\left.83.5 \mathrm{kWhr} / \mathrm{m}^{3}\right)$. It is worth noting that in tests with freshwater pore fluids, the highest increase in the undrained shear strength was reported in the test with the 
TABle 3: Energy consumption for test series 1 and 2.

\begin{tabular}{lcccccc}
\hline \multirow{2}{*}{ Pore fluid } & \multicolumn{2}{c}{ Test series 1 } & \multicolumn{2}{c}{ Energy consumption } \\
& \multicolumn{2}{c}{ Applied voltage: $10 \mathrm{~V}$} & \multicolumn{2}{c}{ Applied voltage: $6 \mathrm{~V}$} & \multicolumn{2}{c}{ Applied voltage: $10 \mathrm{~V}$} \\
& $\mathrm{Whr}$ & $\mathrm{kWhr} / \mathrm{m}^{3}$ & $\mathrm{Whr}$ & $\mathrm{kWhr} / \mathrm{m}^{2}$ & $\mathrm{Whr}$ & $\mathrm{kWhr} / \mathrm{m}^{2}$ \\
\hline Distilled water & 69.1 & 7.4 & 134.4 & 4.3 & 309.2 & 9.1 \\
Lake water & 72.5 & 7.7 & 159.4 & 5.1 & 314.4 & 10.1 \\
Tap water & 73.7 & 7.8 & 167.6 & 5.4 & 399.8 & 12.8 \\
A-seawater & 784.7 & 83.5 & 761.7 & 24.6 & 1994.6 & 63.9 \\
\hline
\end{tabular}

TABLe 4: Loss in the mass of the foundation model after electrokinetic treatment.

\begin{tabular}{lccc}
\hline Pore fluid & $\begin{array}{c}\text { Mass of model } \\
\text { before } \\
\text { electrokinetic } \\
\text { treatment }(\mathrm{g})\end{array}$ & $\begin{array}{c}\text { Mass of model after } \\
\text { electrokinetic } \\
\text { treatment }(\mathrm{g})\end{array}$ & $\begin{array}{c}\text { Loss } \\
\%\end{array}$ \\
\hline $\begin{array}{c}\text { Distilled water: } \\
\text { 6 V }\end{array}$ & 401.6 & 385.8 & 3.9 \\
$10 \mathrm{~V}$ & 401.0 & 377.4 & 5.9 \\
Lake water: & & & \\
6 V & 401.8 & 380.5 & 5.3 \\
$10 \mathrm{~V}$ & 396.2 & 370.7 & 6.4 \\
Tap water: & & & \\
6 V & 402.1 & 377.8 & 6.0 \\
$10 \mathrm{~V}$ & 395.0 & 367.0 & 7.1 \\
A-seawater & & 329.2 & 18.1 \\
$6 \mathrm{~V}$ & 402 & 299.4 & 25.7 \\
\hline $10 \mathrm{~V}$ & 403.0 & & \\
\hline
\end{tabular}

largest energy consumption (tap water pore fluid) and the lowest increase in the shear strength was reported in the test with the smallest energy consumption (distilled water pore fluid).

In test series 2 with $6 \mathrm{~V}$, the energy consumption was $134.4 \mathrm{Whr}\left(4.3 \mathrm{kWhr}\right.$ per $\mathrm{m}^{2}$ of surface area of the foundation model) in the test with distilled water, $159.4 \mathrm{Whr}$ $\left(5.1 \mathrm{kWhr} / \mathrm{m}^{2}\right)$ in the test with lake water, and $167.6 \mathrm{Whr}$ $\left(5.4 \mathrm{kWhr} / \mathrm{m}^{2}\right)$ in the test with tap water. A much higher energy consumption of $761.7 \mathrm{Whr}\left(24.6 \mathrm{kWhr} / \mathrm{m}^{2}\right)$ was reported in the test with A-seawater. In test series 2 with $10 \mathrm{~V}$, the lowest energy consumption was reported in the test with distilled water $\left(309.2 \mathrm{Whr}\right.$ or $\left.10 \mathrm{kWhr} / \mathrm{m}^{2}\right)$ followed by that of lake water $\left(314.4 \mathrm{Whr}\right.$ or $\left.10.1 \mathrm{kWhr} / \mathrm{m}^{2}\right)$ and tap water $\left(399.8 \mathrm{Whr}\right.$ or $\left.12.9 \mathrm{kWhr} / \mathrm{m}^{2}\right)$. Energy consumption of 1994.6 Whr $\left(63.9 \mathrm{kWh} / \mathrm{m}^{2}\right)$ was reported with A-seawater. By comparing the axial load capacity of the foundation model and the energy consumption, it is observed that, with the exception of the test with A-seawater, $\left(Q_{c}\right)_{f}$ increases with the increase in the energy consumption.

Table 4 shows the loss in the mass of the foundation model after electrokinetic treatment. As seen in the table, the lowest loss was for the test with distilled water (3.9\%) and the highest loss in the test with A-seawater (25.7\%). By comparing Tables 3 and 4, it is obvious that the loss in the mass of the foundation model increases with the increase in the electric current and consequently the increase in the energy consumption.

Test series 1 and 2 show that electrokinetics was effective in improving the geotechnical properties with freshwater and highly saline water pore fluids. The energy consumption, however, can significantly increase for treatment in highsaline environment as compared to treatment in fresh water. Thus, consideration of the energy consumption in such environment can be critical for the viability of this technique.

\section{Conclusions}

Two test series were carried out to investigate the feasibility of improving the geotechnical properties of laboratoryprepared soft soil by electrokinetic treatment. Freshwaters (distilled water, lake water, and tap water) and highly saline water (A-seawater) were used to prepare the soil. The investigations included decreasing the water content, increasing the undrained shear strength, and increasing the axial load capacity of a foundation model embedded in the soil. The results showed that electrokinetics improved the geotechnical properties in all tests with the improvement in the tests with freshwater pore fluids being superior to the test with saline water. The best improvement results were reported in the test with tap water pore fluid followed by that of lake water, distilled water, and A-seawater, respectively. The results specifically show the following.

(i) Electrokinetics decreased the water content across most of the soil specimen with the lowest water content near the anode $(28 \% \pm 3.6$ compared to $49.7 \% \pm 3.1$ in the control).

(ii) Electrokinetics increased the untrained shear strength across the soil specimen with the maximum shear strength near the anode $(99.3 \mathrm{kPa} \pm 15.4$ compared to $12.1 \mathrm{kPa} \pm 1.7$ in the control).

(iii) Electrokinetics increased the axial load capacity of the foundation model to $165-325 \mathrm{~N}$ in the tests with $6 \mathrm{~V}$ and $208-416 \mathrm{~N}$ in the tests with $10 \mathrm{~V}$ compared to $27-$ $52 \mathrm{~N}$ in the control. 
(iv) The energy consumption varied between 69.1 and 784.7 Whr (7.4 and $83.5 \mathrm{kWhr}$ per $\mathrm{m}^{3}$ of soil) in test series 1 and between 134.4 and 1994.6 Whr (4.3 and $63.9 \mathrm{kWhr} / \mathrm{m}^{2}$ ) in test series 2 with the lowest energy consumption in the tests with distilled water pore fluid and the highest in the tests with A-seawater pore fluid.

(v) The loss in the mass of the steel foundation model by corrosion varied between $3.95 \%$ and $25.7 \%$ with the smallest loss in the test with distilled water pore fluid and the largest loss in the test with A-seawater pore fluid.

\section{Acknowledgments}

The author would like to acknowledge the contribution of Messrs Elias Hernandez and Rene Siguenza and Ms. Jessica Wong during the experimental program of the study. The research is funded by Natural Science and Engineering Research Council of Canada (NSERC).

\section{References}

[1] M. I. Esrig, "Pore pressure, consolidation and electrokinetics," Journal of the Soil Mechanics and Foundations Division, vol. 94, no. 4, pp. 899-922, 1968.

[2] A. Rittirong, J. Q. Shang, E. Mohamedelhassan, M. A. Ismail, and M. F. Randolph, "Effects of electrode configuration on electrokinetic stabilization for caisson anchors in calcareous sand," Journal of Geotechnical and Geoenvironmental Engineering, vol. 134, no. 3, pp. 352-365, 2008.

[3] S. Micic, J. Q. Shang, and K. Y. Lo, "Electrocementation of a marine clay induced by electrokinetics," International Journal of Offshore and Polar Engineering, vol. 13, no. 4, pp. 308-315, 2003.

[4] E. Mohamedelhassan and J. Q. Shang, "Feasibility assessment of electro-osmotic consolidation on marine sediment," Ground Improvement, vol. 6, no. 4, pp. 145-152, 2002.

[5] A. T. Yeung, "Electro-kinetic flow process in porous media and their applications," in Advances in Porous Media , M. Y. Corapcioglu, Ed., vol. 2, pp. 309-395, Elsevier, Amsterdam, The Netherlands, 1994.

[6] J. K. Mitchell and K. Soga, Fundamentals of Soil Behavior, John Wiley and Sons, New York, NY, USA, 3rd edition, 2005.

[7] J. Q. Shang, "Zeta potential and electroosmotic permeability of clay soils," Canadian Geotechnical Journal, vol. 34, no. 4, pp. 627-631, 1997.

[8] B. Narasimhan and R. S. Ranjan, "Electrokinetic barrier to prevent subsurface contaminant migration: theoretical model development and validation," Journal of Contaminant Hydrology, vol. 42, no. 1, pp. 1-17, 2000.

[9] J. B. Burland, "On the compressibility and shear strength of natural clays," Géotechnique, vol. 40, no. 3, pp. 329-378, 1990.

[10] R. H. Sprute and D. J. Kelsh, Limited Field Tests in Electrokinetic Densification of Mill Tailings, Report of Investigations no. 8034, United States Bureau of Mines, U.S. Department of Interior, Washington, DC, USA, 1975.

[11] E. Mohamedelhassan and J. Q. Shang, "Effects of electrode materials and current intermittence in electro-osmosis," Ground Improvement, vol. 5, no. 1, pp. 3-11, 2001.
[12] S. Micic, J. Q. Shang, K. Y. Lo, Y. N. Lee, and S. W. Lee, "Electrokinetic strengthening of a marine sediment using intermittent current," Canadian Geotechnical Journal, vol. 38, no. 2, pp. 287-302, 2001.

[13] J. Q. Shang, K. Y. Lo, and I. I. Inculet, "Polarization and conduction of clay-water-electrolyte systems," Journal of Geotechnical Engineering, vol. 121, no. 3, pp. 243-248, 1995.

[14] E. Mohamedelhassan and J. Q. Shang, "Electrokineticsgenerated pore fluid and ionic transport in an offshore calcareous soil," Canadian Geotechnical Journal, vol. 40, no. 6, pp. 1185-1199, 2003.

[15] E. Mohamedelhassan and J. Q. Shang, "Electrokinetic cementation of calcareous sand for offshore foundations," International Journal of Offshore and Polar Engineering, vol. 18, no. 1, pp. 73-80, 2008.

[16] K. Tani and W. H. Craig, "Bearing capacity of circular foundations on soft clay of strength increasing with depth," Soils and Foundations, vol. 35, no. 4, pp. 21-35, 1995.

[17] J. L. West and D. I. Stewart, "Effects of zeta potential on soil electrokinetics," in Geoenvironment 2000: Characterization, Containment, Remediation, and Performance in Environmental Geotechnics, Y. B. Acar and D. E. Daniel, Eds., vol. 2 of Geotechnical Special Publication, no. 46, pp. 1535-1549, American Society of Civil Engineers, Reston, Va, USA, 1995. 

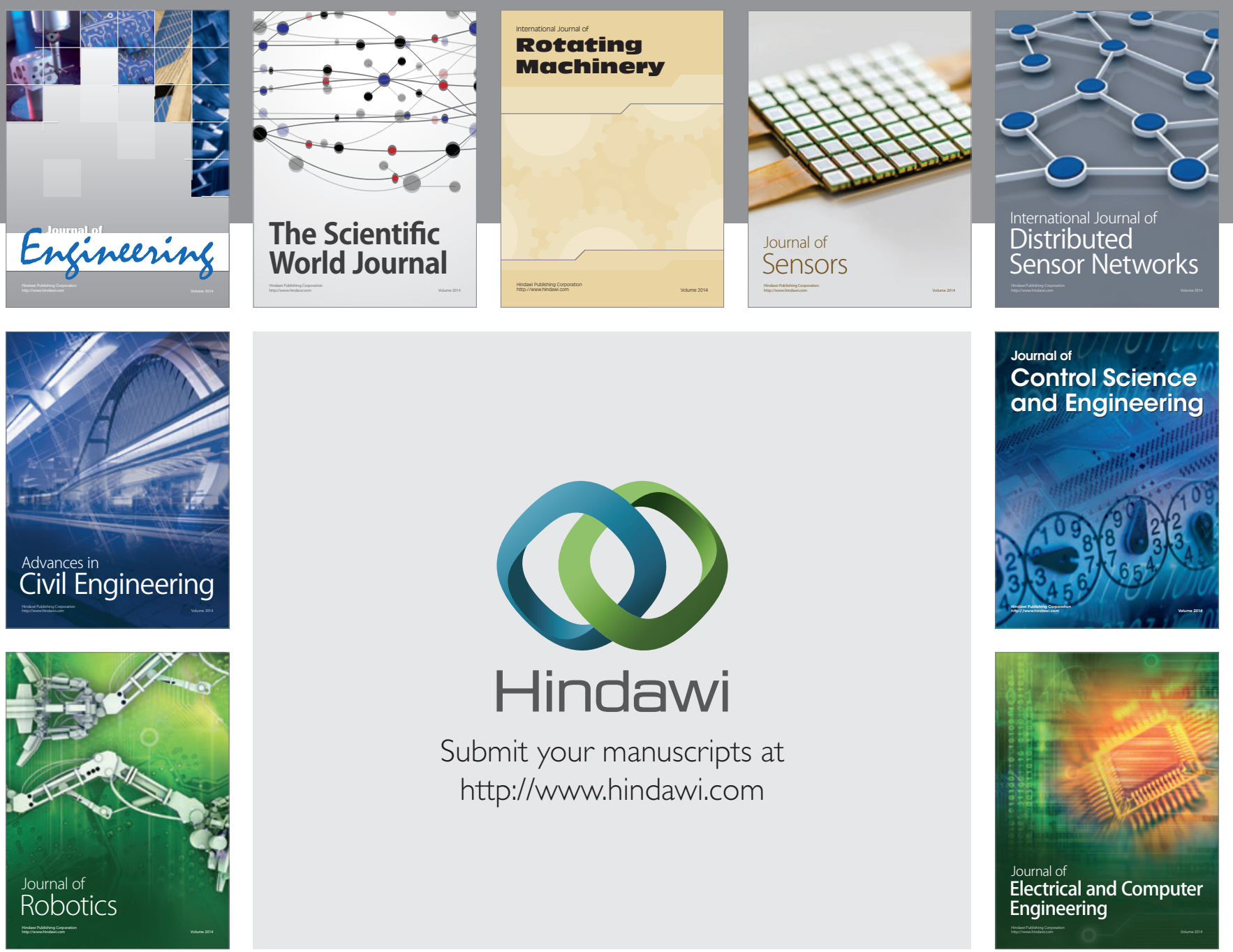

Submit your manuscripts at

http://www.hindawi.com
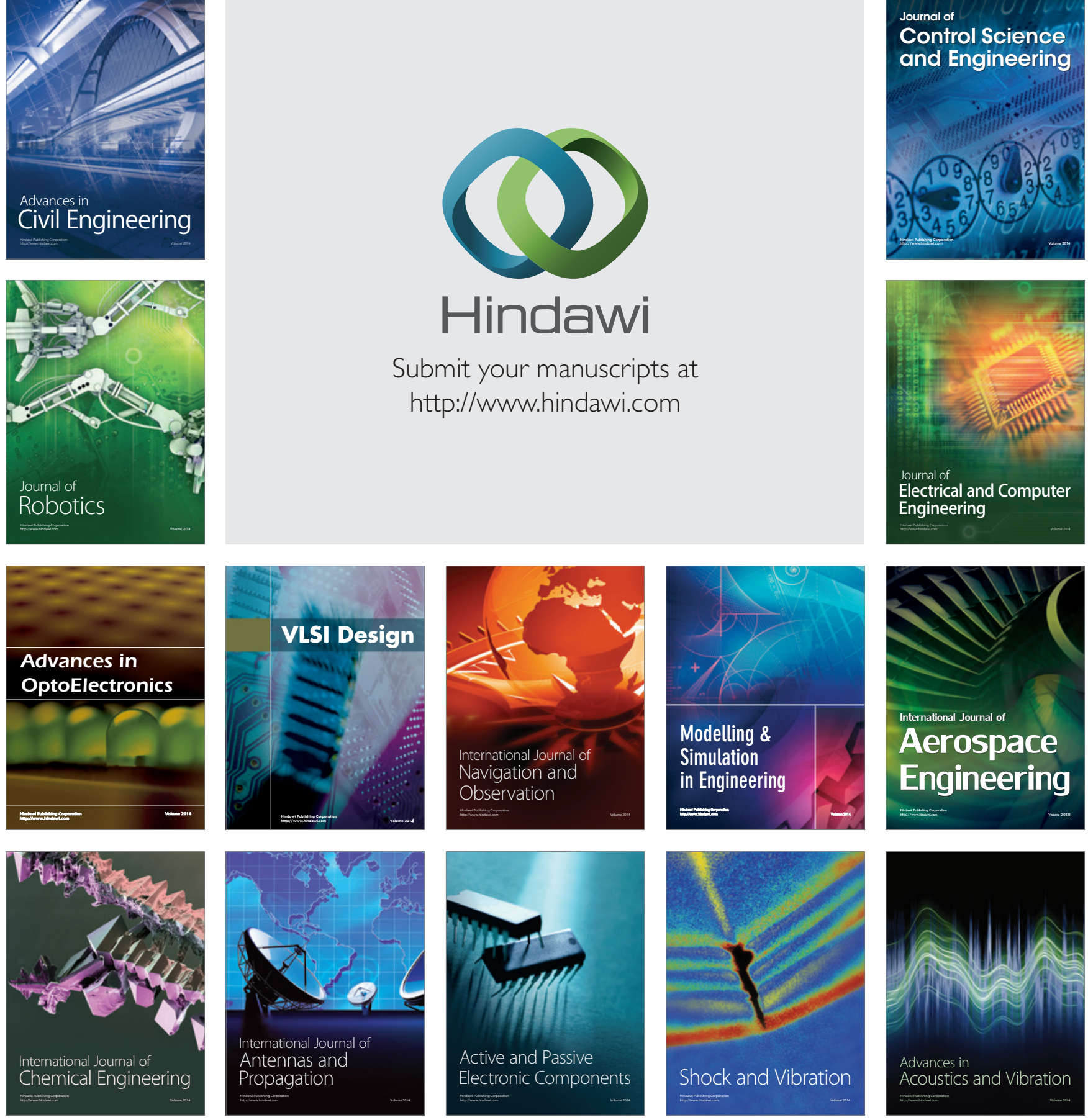